\title{
STRATEGI PERLINDUNGAN BRANDING BATIK KOTA PEKALONGAN MENYONGSONG AFTA 2015 : IDENTIFIKASI, DAN SOLUSI PENERAPAN SOP (STANDARD OPERATING PROCEDURE) "HEALTH ENVIRONMENT \& SAFETY WORKER"
}

\author{
Rr. Vita Nur Latif ${ }^{1}$ Ristiawati $^{2}$, Nor Istiqomah ${ }^{3}$ \\ $(1,2,3)$ Program Studi Kesehatan Masyarakat, Fakultas Ilmu Kesehatan, Universitas \\ Pekalongan
}

\begin{abstract}
Background : AFTA (ASEAN Free Trade Area) is a form of free trade which requires Indonesia to be excellentin terms of products that promote not only quality products but also processes, ensuring quality and standards. Indonesian batik has been recognized by UNESCO as an in tangible cultural Indonesian nation, which mustbeone of exellent products that will participate in the AFTA. Branding the world city of batik for Pekalongan, a positive consequence very proud. But on the other side of the batik processis generally still dependent on raw materials hazardous material negative impact on workers and the environment. The purpose of this study rests on the demands of AFTA (ASEAN Free Trade Area) in 2015 is to improve the quality and the quality and the protectionof domestic products (batik) to be able to compete with foreign products brought marketable products, wherethe production process considering various aspects of health and safety works. Technical outputis generated in the form of data on workers health problems batik, and identification of wastes in this production of Pekalongan City in 2014 through the study and measurement of epidemiology and Environmental Health. Such data as one of the keyst in batik branding strategy formulation protection in the form of a draft SOP and healthy environment for the workers to wards the implementation SMK3 the batik industry with zero accident and zero cases. Results. Batik worker health problems in the form of $67.5 \%$ lungcapacity disorders; $33.8 \%$ decrease invisual function; dermatitis extremities $30 \%$. Distribution of workers with impaired lung capacity, decreased visual function, and dermatitis extremities were observed at the stage of wax sticking, respectively $64.8 \% ; 48.1 \%$; and $66.7 \%$. While the profile of batik waste outlet or point before entry into free waters showed temperature $\left(30^{\circ} \mathrm{C}\right), \mathrm{pH}(9)$, and $\mathrm{COD}(18.7 \mathrm{ppm})$ waste is under the maximum level (safe), where as the levels of $\operatorname{BOD}(162,2 \mathrm{ppm})$ as of yet safe because it is still above the maximum levels of environmental quality standards. Conclusion :Some of the health problems in batik workers found that lung capacity disorders, visual impairment, and dermatitis extremities. While batik waste profile shows temperature, $\mathrm{pH}$, TSS, and COD are under environmental quality standards, but still above the levels of BOD quality standards.
\end{abstract}

Keyword: Batik, health problems, waste

\section{PENDAHULUAN}

AFTA (ASEAN Free Trade Area) merupakan bentuk perdagangan bebas yang menuntut Indonesia untuk lebih unggul dalam hal produk yang mengedepankan tidak hanya kualitas produknya tetapi juga proses yang mengutamakan mutu dan standar. Implementasi AFTA yang direncanakan dilaksanakan pada tahun 2020 diajukan menjadi tahun 2015. Dengan diberlakukannya AFTA yang disepakati bersama oleh semua negara di wilayah
Asia Tenggara maka secara otomatis liberalisasi akan terjadi hampir di semua sektor. Ketika AFTA berlaku pada akhir 2015 nanti pasar Indonesia akan membuka diri. Hal ini menuntut kita untuk meningkatkan kualitas dan mutu serta perlindungan produk dalam negeri tidak terkecuali batik untuk dapat bersaing dengan produk luar negeri dengan mengusung produk layak jual, dimana dalam proses produksinya memperhatikan berbagai aspek kesehatan dan keselamatan kerjanya. 
Batik merupakan produk dalam negeri yang mencirikan kebudayaan dan akan menjadi salah satu produk unggulan Indonesia dalam AFTA. Eksistensi industri kerajinan batik, tidak dapat lepas dari pendapatan daerah dan income per capita wilayah Kota Pekalongan dan menjadi motor penggerak ekonomi mikro maupun makro bagi masyarakatnya. Hal ini membawa konsekuensi positif maupun negatif, diakuinya batik sebagai warisan budaya tak benda berdasarkan pernyataan resmi dari UNESCO (The United Nations Educational, Scientific and Cultural Organization) yaitu badan di bawah Perserikatan Bangsa Bangsa yang mengurusi kebudayaan, telah ditetapkan bahwa batik Indonesia merupakan mata budaya tak benda milik bangsa Indonesia berdasarkan rapat yang diselenggarakan pada tanggal 2 Oktober 2009 di Abu Dhabi, Uni Emirat Arab. Melekatnya branding kota Pekalongan sebagai world city of batik, merupakan konsekuensi positif yang sangat membanggakan. Akan tetapi, pada sisi lain menjamurnya industri batik membawa konsekuensi negatif berupa dampak gangguan kesehatan pada tenaga kerja salah satunya adalah timbulnya gangguan kesehatan yang disebabkan oleh bahan baku pendukung proses produksi pada industri ini. (Widadi, et all, 2010)

Ditinjau dari segi hiperkes salah satu faktor yang menjadi penyebab gangguan kesehatan pada tenaga kerja pada sector industri batik ini adalah adanya bahan-bahan utama atau bahan pendukung proses produksi yang dapat membahayakan atau memberikan efek pada kesehatan para pekerjanya. Dewasa ini lebih dari dua milyar orang hidup dalam lingkungan kerja yang dapat mengancam kesehatan para karyawan industri yang terpajan faktor fisis, kimia, toksis, dan sebagainya yang dapat menimbulkan penyakit akibat kerja.
Secara umum, proses produksi industri batik, menggunakan bahan baku yang pada pengelolaannya menghasilkan polutan yang dapat mengganggu kesehatan pekerjanya. Salah satunya adalah lilin atau lilin batik yang dipanaskan sehingga keluar asap dari lilin tersebut. Polutan yang terdapat dalam asap tersebut mengandung gas-gas $\mathrm{NO}_{2}, \mathrm{SO}_{2}, \mathrm{CO}, \mathrm{CO}_{2}, \mathrm{HC}, \mathrm{H}_{2} \mathrm{~S}$, dan partikel. Hasil penelitian yang telah dilakukan terhadap 327 orang tenaga kerja yang terpapar asap lilin batik dan gas yang dikeluarkan oleh alat pemanas didapatkan gangguan faal paru sebesar $20.7 \%$ dengan perincian obstruksi $11.8 \%$, restriksi $7.8 \%$ dan kombinasi $1.1 \%$. polutan tersebut jika dihirup oleh tenaga kerja akan menimbulkan kerusakan akut maupun kronis pada jaringan paru, tergantung dari konsentrasi polutannya, lama paparan, dan kerentanan tubuh. Bila proses ini berlangsung lama, maka dapat menimbulkan penyakit akibat kerja. Gasgas polutan bersifat iritan terhadap saluran pernapasan terutama gas $\mathrm{SO}_{2}$ dan $\mathrm{NO}_{\mathrm{x}}$. Konsentrasi polutan dipengaruhi oleh kadar bahan-bahan tersebut. Jika dihirup maka akan dapat menimbulkan kelainan pada saluran pernapasan yang berupa penurunan kadar $\mathrm{VO}_{2}$ max dan keluhan saluran pernapasan. (Santoso, 1994)

\section{Polutan lain dapat berupa debu} dengan golongan padat (solid) dan berbentuk fumes atau uap karena dihasilkan dari proses produksi suatu bahan tekstil maupun proses pewarnaan serta bakan kimia lain yang mendukung hasil dari produksi batik. Adapun deskripsi dari gangguan kesehatan ini dapat berupa gangguan kapasitas paru, berbagai gejala dermatitis kontak, gangguan tampilan profil anatomis terkait dengan kondisi ergonomis saat bekerja (low back pain) pada kasuistik tertentu, gangguan pajanan debu (fumes) maupun gangguan kesehatan lainnya. Disamping itu, bahan buangan limbah dari proses produksi batik itu sendiri secara terus menerus apabila 
langsung dibuang ke sungai maupun pada ruang terbuka secara signifikan akan berbanding lurus dengan penurunan daya dukung lingkungan dalam kemampuannya melakukan kompensasi terhadap polutan yang mencemarinya. (Yunus, 1997).

Berdasarkan paparan diatas, eksistensi industri batik membawa dampak negatif dan positif, guna menunjang sisi positif maka perlu dilakukan riset ini. Sajian luaran (output) penelitian ini berupa data mengenai gangguan kesehatan pada industri batik, dan identifikasi limbah hasil produksi batik meliputi kandungan limbah yang dihasilkan. Luaran data gangguan kesehatan dan identifikasi limbah ini dapat menjadi dasar bagi perumusan kebijakan penetapan SOP (standart operational prosedur) mengenai bagaimana praktik kerja aman dengan tetap mewujudkan derajat kesehatan lingkungan guna menjaga daya dukung lingkungan pada industri ini sehingga menjadi solusi menuju Health environment and safety worker, zero accident dan zero kasus gangguan kesehatan pada industri ini dengan tetap menjaga produktivitasnya.

\section{METODE PENELITIAN}

Penelitian ini merupakan penelitian survey analitik dengan metode penelitian deskriptif analitik untuk menyajikan identifikasi gangguan kesehatan yang muncul pada tahapan proses pembuatan batik. Populasi pada penelitian ini adalah seluruh pekerja industri batik diwilayah Kota Pekalongan yang tersebar pada 634 industri batik. Adapun sampel pada penelitian ini sejumlah 80 responden yang diambil secara random sampling.

Pengumpulan data meliputi identitas dan karakteristik responden pekerja, data gangguan kesehatan meliputi gangguan fungsi paru (tampilan kapasitas paru), data gangguan visus, dermatitis, dan gangguan postur akibat sikap kerja.
Beberapa alatpengumpulan data menggunakanfield notes atau catatan lapangan, pedoman wawancara, Spirometer digital, dan cheklist observasi.

Sample untuk identifikasi limbah mengambil 5 lokasi dari lokasi sampel gangguan kesehatan. Pada tiap-tiap lokasi tersebut diambil 3 titik sampling untuk menentukan derajat penurunan konsentrasi limbah. Masing-masing titik dilakukan 3 kali pengulangan. Sehingga total sampel yang diuji adalah 15 sampel air limbah.

Pengujian kualitas kimia air pada penelitian ini meliputi pengukuran suhu, derajat keasaman $(\mathrm{pH})$, oksigen terlarut (DO), kebutuhan oksigen biologis (BOD), kebutuhan oksigen kimiawi (COD), dan salinitas air.

\section{HASIL DAN PEMBAHASAN}

Berdasarkan hasil penelitian didapatkan hasil dari 80 responden pekerja batik selaku sampel terpilih, rata-rata umur 42,78 tahun dengan umur termuda 19 tahun dan umur tertua 78 tahun, jenis kelamin responden terpilih didapatkan laki-laki $36.3 \%$ dan perempuan $63.8 \%$, rerata pendidikan responden adalah SD (77.5\%), dengan pendidikan terendah tidak sekolah $(1.3 \%)$, pendidikan tertinggi SMA (11.3\%), didapatkan kategori IMT normal (52.5\%), underweight (7.5\%), kategori overweight $(40 \%)$. Rata - rata Masa kerja adalah 15 tahun, masa kerja terpendek adalah 1 tahun dan masa kerja terlama 33 tahun, sebagian besar pekerja tidak menggunakan masker yaitu sebanyak 91,3\% dan yang menggunakan masker adalah $8,8 \%$. Berdasarkan jenis tahapan proses kerja pada hasil penelitian didapatkan dari 80 responden terpilih $60 \%$ berada diproses pelekatan lilin, $26.3 \%$ di tahap pewarnaan, dan $7.5 \%$ pada proses nyanting dan $6.3 \%$ pada bagian pelorotan.

A. Gangguan kesehatan makro pekerja batik (tulis dan cap) 
Hasil anamnesa pola gangguan kesehatan makro :

Berdasarkan penelitian didapatkan kesimpulan dari 80 sampel terpilih didapatkan secara makro pada pekerja ditiap tahapan proses pembatikan mengalami keluhan yang spesifik yang hanya timbul pada proses pembatikan tertentu, secara detail dipaparkan pola keluhan sebagai berikut :

\section{1) Tahap pelekatan lilin}

Pada tahap pelekatan lilin (nyanting pada batik tulis dan ngecap pada batik cap) keluhan yang dirasakan pekerja batik adalah sesak nafas dan dada berat, dikarenakan pada proses nyanting pekerja batik melakukan proses peniupan canting secara terus menerus, sehingga uap lilin yang memiliki kandungan bahan kimia terinhalasi, hal ini diperberat dengan kondisi para pekerja batik tulis menghadapi uap yang dihasilkan dari proses pelelehan lilin.dua aktifitas ini apabila dilakukan secara terus menerus mengakibatkan penurunan elastisitas kemampuan paru dalam mengembang sehingga manifestasi dari kondisi adalah keluhan sesak nafas dan dada berat. Keluhan lain adalah Low Back Pain pada proses nyanting dan varises pada proses ngecap yang dikarenakan posisi kerja yang kurang ergonomis (karena pada proses pelekatan lilin ini, baik tulis maupun cap posisi kerja monoton \pm 8 jam perharinya, baik posisi kerja duduk pada proses pelekatan lilin batik tulis maupun posisi kerja berdiri pada proses pelekatan lilin batik cap. Keluhan frozen shoulder dan stress neck juga dirasakan pada keduanya. Keluhan yang banyak muncul pada proses nyanting adalah penurunan daya akomodasi yang tampil pada gangguan visus berupa mata lelah, berair, dan pandangan kabur.

2) Tahap Pewarnaan

Pada tahapan pewarnaan didapatkan hasil keluhan kesehatan berupa gatal pada permukaan kulit tangan dan kaki, penipisan lapisan epidermis yang disebabkan penggunaan pewarnaan tanpa menggunakan alat pelindung diri yang memadai, seperti : sarung tangan dan sepatu boot, sehingga bahan kimia langsung terpajan pada kulit pekerja. Penggunaan kaporit sebagai bahan pembersih tangan setelah terpajan bahan pewarna menyebabkan penipisan pada kulit tangan maupun kaki pekerja batik. Pada proses pewarnaan manual (tanpa mesin) didapati keluhan low back pain) dikarenakan proses kerja posisi membungkuk dan berdiri secara berulang-ulang.

\section{3) Tahap pelepasan lilin}

Pada tahap pelorotan didapatkan hasil keluhan kesehatan berupa sesak nafas, dan dada berat, mata berair dan didapatkan sebagian sampel pekerja batik pada tahap ini mengalami defek anatomis berupa lordosis dan kifosis. Keluhan sesak nafas dan dada berat disebabkan karena uap pelelehan lilin dan biomassa yang dihasilkan dari proses pembakaran kayu yang digunakan untuk pelelehan lilin. Pajanan secara terus menerus uap pelehan lilin dan biomassa (bagi industry batik yang masih menggunakan kayubakar sebagai bahan bakar pelorotan) menyebabkan penurunan elastisitas kemampuan paru untuk mengembang sehingga manifestasi kondisi ini berupa sesak nafas, dada berat dan mata berair.

B. Gangguan kesehatan berdasarkan hasil pengukuran pada pekerja batik 
Beberapa gangguan kesehatan yang ditemukan pada pekerja batik di antaranya seperti tabel berikut.

Tabel 1. Distribusi gangguan kesehatan pada pekerja batik

\begin{tabular}{lcc}
\hline Gangguan & \multicolumn{2}{c}{ Frekuensi (\%) } \\
& Normal & $\begin{array}{c}\text { Tidak } \\
\text { normal }\end{array}$ \\
\hline Kapasitas & 32,5 & 67,5 \\
paru & & \\
Visus & 66,2 & 33,8 \\
Dermatitis & 70 & 30 \\
\hline
\end{tabular}

Dari $67,5 \%$ responden dengan gangguan kapasitas paru dapat dikategorikan seperti gambar berikut.

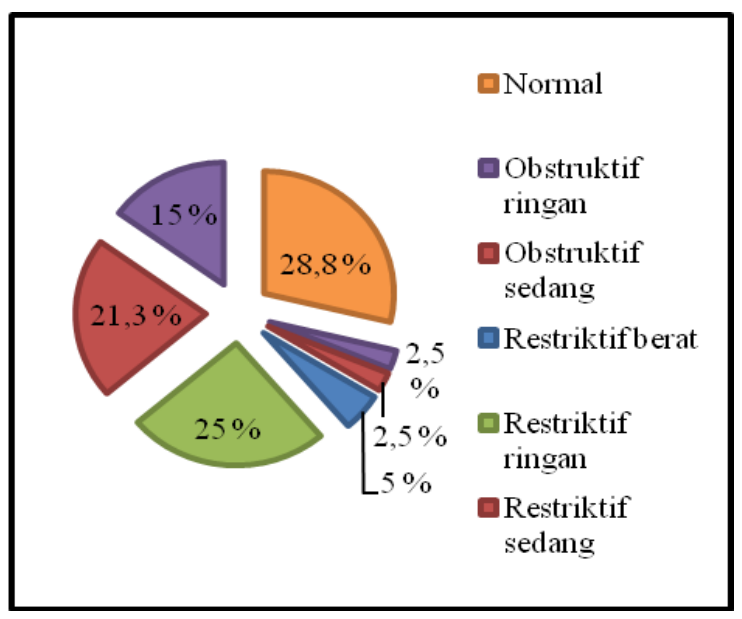

Gambar 2. Kategori gangguan kapasitas paru yang ditemukan

Berdasarkan hasil pengukuran visus didapatkan $33.8 \%$ responden mengalami penurunan fungsi penglihatan, berupa pandangan mata kabur, minus. Adapun gangguan kesehatan pada daya lihat yang dikeluhkan diantaranya adalah mata lelah, berair yang banyak didapatkan pada pekerja batik pada proses nyanting.

Berdasarkan hasil penelitian dermatitis didapatkan $30 \%$ responden mengalami kondisi dermatitis baik pada ekstremitas tangan maupun kaki.
Hal ini disebabkan pajanan bahan kimia pada proses pewarnaan secara terus menerus tanpa barrier alat pelindung diri (boot dan sarung tangan).

Adapun keluhan keluhan gangguan kesehatan yang dirasakan para pekerja didapatkan sebagai berikut :

1. Pada tahap pelekatan lilin (nyanting pada batik tulis dan ngecap pada batik cap) keluhan yang dirasakan pekerja batik adalah sesak nafas dan dada berat, dikarenakan pada proses nyanting pekerja batik melakukan proses peniupan canting secara terus menerus, sehingga uap lilin yang memiliki kandungan bahan kimia terinhalasi, hal ini diperberat dengan kondisi para pekerja batik tulis menghadapi uap yang dihasilkan dari proses pelelehan lilin.dua aktifitas ini apabila dilakukan secara terus menerus mengakibatkan penurunan elastisitas kemampuan paru dalam mengembang sehingga manifestasi dari kondisi adalah keluhan sesak nafas dan dada berat. Keluhan lain adalah Low Back Pain pada proses nyanting dan varises pada proses ngecap yang dikarenakan posisi kerja yang kurang ergonomis (karena pada proses pelekatan lilin ini, baik tulis maupun cap posisi kerja monoton \pm 8 jam perharinya, baik posisi kerja duduk pada proses pelekatan lilin batik tulis maupun posisi kerja berdiri pada proses pelekatan lilin batik cap. Keluhan frozen shoulder dan stress neck juga dirasakan pada keduanya. Keluhan yang banyak muncul pada proses nyanting adalah penurunan daya akomodasi yang tampil pada gangguan visus berupa mata lelah, berair, dan pandangan kabur. 
2. Pada tahapan pewarnaan didapatkan hasil keluhan kesehatan berupa gatal pada permukaan kulit tangan dan kaki, penipisan lapisan epidermis yang disebabkan penggunaan pewarnaan tanpa menggunakan alat pelindung diri yang memadai, seperti : sarung tangan dan sepatu boot, sehingga bahan kimia langsung terpajan pada kulit pekerja. Penggunaan kaporit sebagai bahan pembersih tangan setelah terpajan bahan pewarna menyebabkan penipisan pada kulit tangan maupun kaki pekerja batik. Pada proses pewarnaan manual (tanpa mesin) didapati keluhan low back pain) dikarenakan proses kerja posisi membungkuk dan berdiri secara berulang-ulang.

3. Pada tahap pelorotan didapatkan hasil keluhan kesehatan berupa sesak nafas, dan dada berat, mata berair dan didapatkan sebagian sampel pekerja batik pada tahap ini mengalami defek anatomis berupa lordosis dan kifosis. Keluhan sesak nafas dan dada berat disebabkan karena uap pelelehan lilin dan biomassa yang dihasilkan dari proses pembakaran kayu yang digunakan untuk pelelehan lilin. Pajanan secara terus menerus uap pelehan lilin dan biomassa (bagi industry batik yang masih menggunakan kayubakar sebagai bahan bakar pelorotan) menyebabkan penurunan elastisitas kemampuan paru untuk mengembang sehingga manifestasi kondisi ini berupa sesak nafas, dada berat dan mata berair.
Manifestasi Gangguan kesehatan yang muncul pada tiap proses pembatikan (pelekatan lilin, pewarnaan dan pelorotan) bersifat spesifik, artinya keluhan dan gangguan kesehatan pada proses pelekatan lilin spesifik hanya diderita oleh pekerja pada bagian itu. Begitu juga pada tahap pewarnaan maupun pelorotan.

Kondisi gangguan yang muncul sebagai hasil penelitian sesuai dengan teori mengenai kandungan lilin batik seperti Hidrogen peroksida $\left(\mathrm{H}_{2} \mathrm{O}_{2}\right)$ dan paraffin keduanya menyebabkan iritasi paru apabila terinhalasi secara continue dalam jangka waktu yang lama karena bersifat korosif pada jaringan organ paru. Hal ini terbukti pada manifestasi keluhan pekerja pada proses pelekatan lilin (baik itu proses nyanting maupun cap), para pekerja batik memiliki keluhan sesak nafas dan dada terasa berat. Adapun gangguan kesehatan berupa dermatitis baik karena penyebab iritasi terhadap bahan kimia pewarnaan, seperti senyawa Sodium Hidroksida $(\mathrm{NaOH})$ dan Asam Clorida $(\mathrm{HCl})$ serta Sodium Nitrit $\left(\mathrm{NaNO}_{2}\right)$ dimana ketiga senyawa tersebut bersifat iritatif dengan manifestasi peradangan pada kulit, kondisi ini diperberat dengan kondisi fisik lingkungan kerja yang kurang menjaga hygiene.

C. Profil limbah batik

Berdasarkan hasil penelitian limbah, didapatkan profil limbah batik seperti tabel 4. 
Tabel 4. Gambaran kandungan limbah batik Kelurahan Kauman

\begin{tabular}{|c|c|c|c|c|c|}
\hline Parameter & Titik & Pasca industri & Vilai & outlet & $\begin{array}{l}\text { Baku } \\
\text { mutu } \\
\text { (maks)* }\end{array}$ \\
\hline Suhu $\left({ }^{0} \mathrm{C}\right)$ & $\begin{array}{l}1 \\
2 \\
3\end{array}$ & $\begin{array}{l}32(29-32){ }^{0} \mathrm{C} \\
29(28-29){ }^{0} \mathrm{C} \\
29(27-29){ }^{0} \mathrm{C}\end{array}$ & $27^{\circ} \mathrm{C}$ & $30^{\circ} \mathrm{C}$ & $38^{0} \mathrm{C}$ \\
\hline pH & $\begin{array}{l}1 \\
2 \\
3\end{array}$ & $\begin{array}{l}10,08 \pm 0,487 \\
8 \pm 1,366 \\
7,44 \pm 0,808\end{array}$ & 7 & 9 & $6-9$ \\
\hline $\begin{array}{l}\text { BOD } \\
(\mathbf{p p m})\end{array}$ & $\begin{array}{l}1 \\
2 \\
3\end{array}$ & $\begin{array}{l}131,8 \pm 10,83 \\
94 \pm 14,28 \\
67,6 \pm 11,17\end{array}$ & 10,9 & 162,2 & 60 \\
\hline $\begin{array}{l}\text { COD } \\
(p p m)\end{array}$ & $\begin{array}{l}1 \\
2 \\
3\end{array}$ & $\begin{array}{l}346,6 \quad \pm \\
111,224 \\
246,8 \pm 61,386 \\
161,8 \pm 13,027\end{array}$ & 301 & 18,7 & 150 \\
\hline $\begin{array}{l}\text { Salinitas } \\
(\mathbf{p p m})\end{array}$ & $\begin{array}{l}1 \\
2 \\
3\end{array}$ & $\begin{array}{l}25(15-60) \\
2(2-4) \\
2(2-4)\end{array}$ & & & \\
\hline
\end{tabular}

* Peraturan Daerah Provinsi Jawa Tengah no 5 tahun 2012

Terlihat pada tabel bahwa air limbah yang keluar dari industri batik memiliki karakteristik suhu $29^{\circ} \mathrm{C} ; \mathrm{pH}$ 7,44; BOD 67,6; COD 161,8; dan salinitas $2 \%$. Secara umum limbah cair industri batik kelurahan Kauman sudah ramah lingkungan, hanya pada kadar BOD dan COD yang melebihi baku mutu. Limbah atau buangan hasil produksi batik sebagian besar berasal dari zat warna yang digunakan.Dalam hal ini semua produsen batik di Kelurahan Kauman sudah tidak menggunakan bahan pewarna naphtol yang banyak menyumbang bahan pencemar.

Kondisi limbah cair pada titik 1 sangat ekstrim dengan nilai pada masing-masing parameter jauh lebih tinggi dibandingkan baku mutu. Titik 1 diambil dari aliran air terdekat dari proses pemlorotan, sehingga merupakan titik awal bahan pencemar masuk dalam air. Nilai parameter kemudian mengalami penurunan pada titik 2 hingga 3. Titik 2 diambil dari aliran air tengah, setelah proses pembilasan ke dua. Sedangkan titik 3 diambil tepat saat air keluar menuju selokan.Suhu air tampak tidak mengalami penurunan secara nyata dikarenakan letak pengambilan titik 13 yang berdekatan, sehingga perubahan suhu tidak banyak terjadi. Titik 1 pada semua industri itemukan memiliki suhu paling tinggi dibandingkan titik 2 dan 3, dikarenakan lokasi tersebut paling dekat dengan proses pemlorotan yang menggunakan tungku untuk melepaskan lilin dari kain.

$\mathrm{pH}$ air menunjukkan penurunan dari titik 1 hingga 3, meski masih berada pada kisaran basa. Kondisi basa disebabkan ada penambahan soda pada proses pemlorotan. Angka BOD yang tinggi menunjukkan kebutuhan oksigen yang tinggi untuk menetralisir bahan buangan oleh mikroorganisme. Angka tersebut berbanding terbalik 
dengan kadar oksigen terlarut. Tingginya polutan yang masuk dalam air akan meningkatkan kebutuhan mikroorganisme akan oksigen. Sehingga tampak pada tabel titik 1 memiliki angka BOD paling tinggi dan terus menurun pada titik 2 dan 3 . Sama halnya dengan BOD, COD juga merupakan kadar kebutuhan oksigen tapi oleh unsur-unsur kimia untuk melakukan reaksi oksidasi menetralkan bahan pencemar. Angka tersebut harus dikendalikan hingga di bawah baku mutu lingkungan sebelum bergabung dengan badan air / sungai. Dalam hal ini ditemukan kadar COD tinggi pada titik terdekat dengan proses pemlorotan dan menurun seiring dengan penambahan jarak pada titik 2 dan 3.

Selain titik keluarnya air limbah tepat setelah industri, kondisi limbah juga diukur sebelum dan sesudah IPAL (inlet dan outlet). Inlet merupakan air limbah yang masuk menuju instalasi pengolahan air limbah (IPAL), yang bersumber dari akumulasi limbah seluruh industri batik rumahan di Kelurahan Kauman. Outlet merupakan air limbah yang sudah mengalami pengolahan oleh IPAL dan siap untuk dibuang menuju badan sungai.

Suhu dan $\mathrm{pH}$ limbah baik inlet maupun outlet menunjukkan kondisi normal atau di bawah baku mutu, sehingga dapat dikatakan air limbah yang menuju badan sungai sudah baik dan aman suhu dan keasamannya. Menariknya, kadar BOD inlet terhitung aman di bawah baku mutu, akan tetapi justru setelah melalui pengolahan oleh IPAL kadar BOD terhitung tinggi melebihi batas baku mutu. Sebaliknya, kadar COD inlet terhitung tidak aman atau jauh melebihi kadar baku mutu, sedangkan
COD outlet menurun jauh di bawah baku mutu.

Kadar COD yang tinggi pada inlet menunjukkan banyaknya unsur kimia yang butuh melakukan oksidasi untuk netralisasi, sehingga kebutuhan oksigen sangat tinggi. Seperti yang telah diketahui bersama, bahwa proses pembatikan banyak menggunakan zat kimia pada tiap tahapannya. Setelah dilakukan pengolahan limbah dengan IPAL model aerasi, maka kadar COD menurun hingga kadar yang aman untuk lingkungan.

Sebaliknya, pada kadar BOD inlet yang rendah memiliki 2 kemungkinan, pertama, minimnya mikroorganisme yang hidup dalam air limbah sehingga kebutuhan oksigen untuk respirasi dalam rangka netralisasi bahan pencemar juga rendah. Atau kedua, memang tidak adanya mikroorganisme yang hidup, sehingga netralisasi dilakukan dengan cara oksidasi unsur kimia. Kadar BOD outlet yang tinggi (162,2 ppm) dimungkinkan karena adanya penambahan mikroorganisme dalam IPAL yang justru menuntut kebutuhan oksigen untuk respirasi dan netralisasi bahan pencemar. (Adi BW, 2012)

Secara umum data limbah ini mengindikasi bahwa limbah batik yang dalam hal ini adalah batik tulis dan cap di Kota Pekalongan tidak berkontribusi mutlak dalam pencemaran air sungai, perlu diadakan kajian lanjut mengenai kandungan limbah untuk contributor limbah lainnya seperti batik printing dan jeanswash.

\section{SIMPULAN}

Berdasarkan penelitian maka dapat diambil simpulan sebagai berikut: 
1. Ditemukan gangguan kesehatan pada pekerja batik di antaranya gangguan kapasitas paru $67,5 \%$, penurunan fungsi penglihatan 33,8\%, dan dermatitis ekstrimitas 30\%. Adapun sebaran pekerja dengan gangguan kapasitas paru, penurunan fungsi penglihatan, dan dermatitis ekstrimitas terbanyak ditemukan pada tahap pelekatan lilin, berturut-turut $64,8 \%$; $48,1 \%$; dan $66,7 \%$.

2. Profil limbah batik ditemukan suhu $29^{\circ} \mathrm{C}, \mathrm{pH} 7,44 \pm 0,808$, kadar BOD $67,6 \pm 11,17$ ppm, COD 161,8 \pm 13,027 ppm, dan salinitas 2 (2-4) \%o. Parameter suhu dan $\mathrm{pH}$ berada di bawah angka baku mutu limbah yang tertulis pada peraturan Daerah Propinsi Jawa Tengah no 5 tahun 2012. Akan tetapi kadar BOD dan COD yang ditemukan melebihi baku mutu yang ditetapkan. Namun demikian, pengukuran baku mutu yang dilakukan pada titik outlet (setelah IPAL) menunjukkan suhu $\left(30^{\circ} \mathrm{C}\right), \mathrm{pH}$ (9), dan COD (18,7 ppm) limbah berada di bawah kadar maksimum, sedangkan kadar BOD (162,2 ppm) terhitung belum aman karena masih di atas kadar maksimum baku mutu lingkungan.

\section{SARAN}

Beberapa hal yang sebaiknya dilakukan di antaranya:

1. Perlu penerapan manual procedure sebagai panduan bekerja yang sehat dan menyehatkan (health environment and safety worker)

2. Perlu adanya pemeriksaan berkala tentang kesehatan pekerja untuk memonitor kesehatannya dalam rangka peningkatan kinerja

3. Para pekerja batik sebaiknya menggunakan Alat Pelindung Diri saat bekerja
4. Perlu penelitian lebih lanjut dengan studi komparasi maupun korelasi beberapa temuan variabel penurunan derajat kesehatan dengan tahapan pekerjaan

5. Para pemilik indutri batik secara berkala melakukan maintenance terhadap saluran pembuangan air limbah agar tidak bocor ke sanitasi umum

\section{DAFTAR PUSTAKA}

Adi BW, 2012. Penyisihan Zat Organik Pada Air Limbah Industri Bati Dengan Fotokatalisis $\mathrm{TiO}_{2}$. Jurusan Teknik Lingkungan FTSP Institut Teknologi Surabaya.

Amaliasani, R. 2013. Pengolahan Limbah Batik dengan menggunakan metode elektrolisis dengan anoda dan katoda platinum $(P t)$. Universitas Islam Indonesia. Yogyakarta.

Arikunto, Suharsimi. 2001. Prosedur Penelitian Suatu Pendekatan Praktek. Rineka cipta. Jakarta.

Brockopp, Dorothy young. 1999. Dasardasar riset keperawatan. ECG. Jakarta.

Karsidi, Ravik. 2000. Pengembangan Instrumen dalam penelitian sosial. Makalah disampaikan dalam Latihan penelitian tingkat dasar / LPTD.

Kerlinger. Asas-asas penelitian behavioural. Gadjah mada university press. Yogyakarta.

Kusnanto, Hari. Metode Kualitatif dalam riset Kesehatan. Program Studi Ilmu Kesehatan Masyarakat Pascasarjana Universitas Gadjah Mada. Yogyakarta.

Machfoed, Ircham. Metode penelitian di bidang kesehatan. 
Notoatmodjo, Soekidjo. 2002. Metodologi Penelitian Kesehatan. Rineka cipta. Jakarta.

Peraturan Daerah Provinsi Jawa Tengah Nomor 5 tahun 2012 Tentang Perubahan atas Peraturan Daerah Provinsi Jawa Tengah Nomor 10 Tahun 2004 Tentang baku Mutu Air Limbah.

Pratama D. 2012. Pengolahan Limbah Batik Yang Berwawasan Lingkungan. Universitas Jember.

Pratiknya, Watik. 2001. Dasar-dasar Metodologi Penelitian Kedokteran dan Kesehatan. Raja Grafindo. Jakarta.

Santoso, Gangguan Faal Paru pada Pekerja Batik di Kodya Surakarta, Universitas Indonesia, Disertasi, Jakarta,

Sasongko, DP dan WP Tresna. 2010. Identifikasi Unsur dan Kadar Logam Berat pada Limbah Pewarna Batik dengan Metode Analisis Pengaktifan Neutron. Jurnal Ilmu Pengetahuan dan Teknologi TELAAH. Vol.27.

Sugiyono. 2002. Statistika untuk Penelitian. Alfabeta. Bandung.

Supriyanto C., Kris Tri Basuki dan A. Purwanto. 2005. Identifikasi LogamLogam Berat Fe, Cr, Mn, $\mathrm{Mg}, \mathrm{Ca}$, dan Na Dalam Air Tangki Reaktor Dengan Metode Nyala Spektrometri Serapan Atom (SAA). Prosiding PPI -PDIPTN $2005 \quad$ Puslitbang Teknologi Maju-BATAN Jogjakarta, 12 Juli 2005.

Widadi, et all, Kajian Dampak Pengukuhan UNESCO terhadap Batik Indonesia sebagai Warisan Tak Benda, Direktorat Jendral Industri Kecil dan Menengah Kementrian Perindustrian RI, 2010.
Yunus, F, Dampak Debu Industri pada Paru dan Pengendaliannya, Jurnal Respirologi Indonesia, vol.17. Tahun 1997. 